\title{
Bimbingan Aplikasi Sistem Hibrid Genset dan Photovoltaic pada Masyarakat Nelayan di Suppa Kabupaten Pinrang
}

\author{
Syerly Klara ${ }^{1 *}$, Faisal Mahmuddin ${ }^{1}, \operatorname{Hamzah}^{2}$, Samsuddin Amin $^{3}$, Irwan Setiawan ${ }^{4}$, Arwin Amiruddin ${ }^{5}$, Mansyur \\ Hasbullah $^{2}$ \\ ${ }^{*}$ Departemen Teknik Sistem Perkapalan, Fakultas Teknik, Universitas Hasanuddin. \\ ${ }^{2}$ Departemen Teknik Sistem Perkapalan, Fakultas Teknik, Universitas Hasanuddin \\ ${ }^{3}$ Departemen Teknik Arsitektur, Fakultas Teknik, Universitas Hasanuddin \\ ${ }^{4}$ Departemen Teknik Industri, Fakultas Teknik, Universitas Hasanuddin \\ ${ }^{5}$ Departemen Teknik Sipil, Fakultas Teknik, Universitas Hasanuddin \\ elikapal@yahoo.com
}

\begin{abstract}
Abstrak
Desa Marabombang, Kecamatan Suppa, Kabupaten Pinrang merupakan sebuah desa yang berbatasan dengan selat Makassar. Karena lokasi geographis yang berbatasan dengan laut ini, maka sebagian penduduk Desa Marabombang berprofesi sebagai nelayan. Berbagai macam alat tangkap digunakan oleh masyarakat desa untuk mendapatkan ikan baik dengan menggunakan kapal maupun dengan bagan. Namun demikian, nelayan Desa Marabombang menghadapi kendala utama dalam melakukan aktivitasnya yakni semakin tingginya biaya bahan bakar atau energi. Untuk itu, pada program pengabdian yang akan dilakukan ini, masyarakat akan diperkenalkan dan dilatih untuk dapat memanfaatkan sistem hibrid genset dan energi matahari atau sistem photovoltaic. Kegiatan ini akan berlangsung selama sekitar 6 bulan mulai dari persiapan sampai penyusunan laporan dan publikasi. Kegiatan utama yang dilakukan pada program pengabdian ini adalah pelatihan dan penjelasan tentang komponen, cara pemakaian dan perawatan, serta hal lain yang berhubungan dengan sistem hibrid genset dan photovoltaic. Selain itu, untuk meningkatkan pemahaman masyarakat, maka kegiatan penjelasan ini akan diikuti dengan praktek langsung penggunaan sistem di bagan yang sudah ada. Dengan kegiatan pengabdian ini, maka diharapkan pemahaman masyarakat tentang penggunaan sistem hibrid genset dan photovoltaic dapat meningkat sehingga masyarakat dapat menggunakan sistem tersebut untuk meningkatkan produktivitas dan kesejahteraan terutama oleh nelayan bagan ikan di tempat pelaksanaan kegiatan ini.
\end{abstract}

Kata Kunci: bagan ikan; energi surya; nelayan; pelatihan dan bimbingan; sistem hibrid.

\section{Pendahuluan}

Kecamatan Suppa merupakan salah satu kecamatan yang ada di Kabupaten Pinrang, Sulawesi Selatan. Kecamatan ini berjarak sekitar $180 \mathrm{~km}$ dari Kota Makassar yang merupakan ibukota Provinsi Sulawesi Selatan. Secara geografis, Kecamatan Suppa berbatasan dengan; sebelah utara berbatasan dengan Kabupaten Tana Toraja, sebelah selatan berbatasan dengan Kota Parepare, sebelah barat berbatasan dengan Kabupaten Polman dan Selat Makassar, dan sebelah timur berbatasan dengan Kabupaten Enrekang dan Kabupaten Sidrap. Kecamatan Suppa memiliki 2 kelurahan dan 8 Desa, yaitu : Kelurahan Watang Suppa, Kelurahan Marabombang, Desa Marabombang, Desa Watang Pulu, Desa Maritengngae, Desa Tasiwalie, Desa Wiring Tasi, Desa Lotang Salo, Desa Ujung Labuang, Desa Polewali.

Kecamatan ini memiliki batas-batas yaitu :

- Sebelah Utara : Kecamatan Lanrisang dan Mattirobulu

- Sebelah Timur : Kabupaten Sidereng Rappang dan Kota Parepare

- Sebelah Selatan : Selat Makassar dan Teluk Parepare

- Sebelah Barat : Selat Makassar 
Kecamatan Suppa memiliki luas $74.20 \mathrm{~km}^{2}$ dengan ketinggian dari permukaan laut $265 \mathrm{mdpl}$ merupakan daerah yang kaya akan potensi pertanian, perikanan. Melihat letak geografis dimana kecamatan merupakan daerah yang datar, yang identik dengan pertanian dan tambak. Memasuki daerah di Suppa kita disuguhi pemandangan yang eksotis lahan pertanian penduduk dan tambak yang terhampar luas. Peta Kecamatan Suppa dapat dilihat pada gambar berikut:

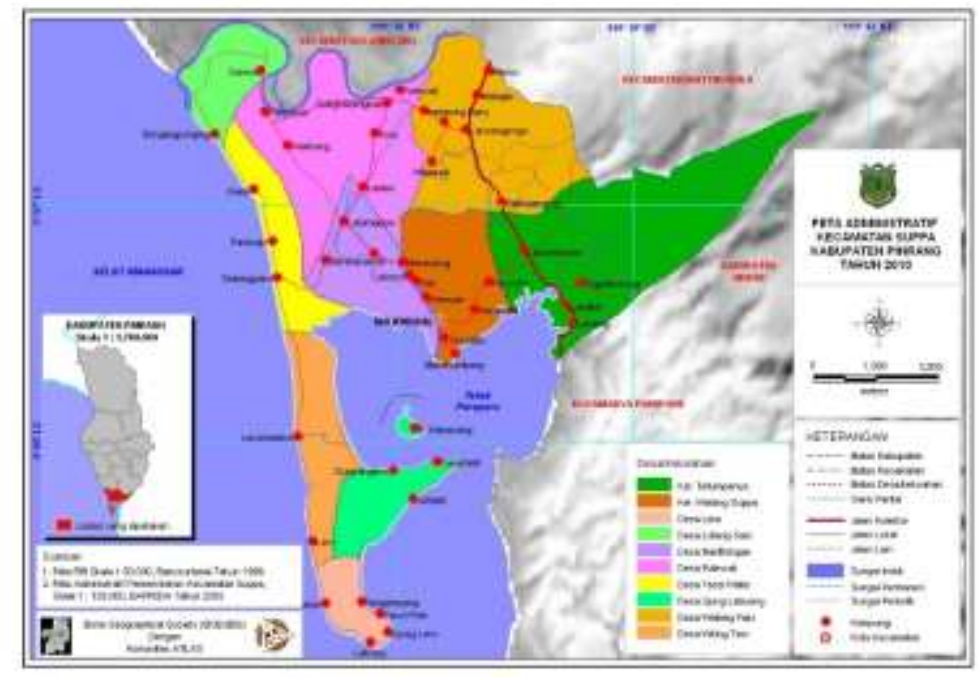

Gambar 1. Peta Kecamatan Suppa

(Sumber: http://komunitas-atlas.blogspot.com/2010/11/kecamatan-suppa.html)

Sekilas salah satu desa yang berada di wilayah Kecamatan Suppa yaitu Desa Marabombang dengan luas $51 \mathrm{ha} / \mathrm{m}^{2}$ atau 6,5 bujur sangkar menurut Kepala Desa Marabombang. Wilayah Desa Marabombang sebagian besar digunakan untuk kegiatan kenelayanan karena Desa Marabombang memiliki luas tepi pantai pesisir yang mengelilingi daratan wilayah Desa Marabombang yang hampir sama luasnya dengan luas Desa Marabombang.

Secara geografis dan administratif Desa Marabombang memiliki batas-batas wilayah sebagai berikut:

- Sebelah Utara : berbatasan dengan Desa Tasallu

- Sebelah Selatan : berbatasan dengan Teluk Parepare

- Sebelah Timur : berbatasan dengan Teluk Parepare

- Sebelah Barat : berbatasan dengan Desa Marettengae

Sumber mata pencarian penduduk Desa Marabombang terpusat pada kegiatan kenelayanan, yang mana hampir semua penduduk di desa ini menggantungkan hidupnya pada hasil laut yang hasilnya kadang banyak, kadang sedikit bahkan kadang tidak ada sama sekali. Hal ini sudah terpola dari alam dan tertanam pada masing-masing individu yang melakukan kegiatan kenelayanan. Dalam menunjang kelangsungan hidup, tentunya masyarakat mencari alternatif lain untuk melakukan diversifikasi pekerjaan atau pekerjaan sampingan seperti membangun mitra kerja, menjadi buruh, kuli bangunan, tukang kayu pedagang eceran, penenun ataupun pekerjaan lainnya. Walau demikian, dapat digambarkan bahwa orientasi masyarakat di Desa Marabombang umumnya bermata pencarian sebagai nelayan dengan memanfaatkan sumber daya alam yang ada di desa tersebut. 
Di samping itu, ketergantungan terhadap musim sangat tinggi dan tidak setiap saat nelayan bisa melaut, terutama pada musim ombak, yang berlangsung selama berbulan-bulan. Akibatnya, tidak ada hasil tangkapan yang diperoleh pada saat itu. Kondisi ini jelas tidak menguntungkan nelayan karena secara riil rata-rata pendapatan perbulan menjadi lebih kecil, dan pendapatan yang diperoleh pada saat musim ikan, akan habis dikonsumsi pada saat paceklik. Rendahnya nilai tukar ikan, mahalnya harga kebutuhan sehari-hari dan besarnya tanggungan keluarga juga merupakan faktor penyebab kemiskinan.

Selain faktor cuaca tersebut, rendahnya pendapatan masyarakat juga diakibatkan oleh biaya operasional penangkapan yang cukup tinggi. Salah satu biaya operasional tersebut adalah bahan bakar yang digunakan untuk melaut atau untuk mengoperasikan bagan. Bahan bakar ini sebagian digunakan untuk menyalakan genset yang dapat menghasilkan listrik yang dibutuhkan untuk proses penangkapan ikan. Dengan demikian, diperlukan solusi untuk meningkatkan produktivitas mereka dengan memanfaatkan sumber energi terbarukan seperti energi matahari.

Energi surya ini sangat cocok dimanfaatkan pada bagan selain karena intensitas sinar matahari yang cukup besar dilaut, bentuk bagan juga sangat ideal untuk menempatkan modul surya karena terdapatnya ruang-ruang kosong diatas bagan yang cukup luas (Santosa \& Mulyatno, 2014). Dengan luasnya ruang-ruang kosong tersebut, jumlah modul atau sistem photovoltaic yang dapat dioperasikan cukup banyak sehingga energi listrik yang dihasilkan dari sistem juga akan cukup besar (Syah, dkk., 2014).

Untuk dapat mengenalkan pemanfaatan sistem hibrid genset dan photovoltaic, maka kegiatan pengabdian yang diusulkan ini akan memberikan pelatihan dan bimbingan tentang komponenkomponen, cara kerja dan pengoperasian, dan perawatan sistem hibrid genset dan photovoltaic pada masyarakat nelayan desa Marabombang, kabupaten Pinrang. Kegiatan penjelasan ini akan diikuti dengan praktek langsung penggunaan sistem tersebut. Kelompok masyarakat yang menjadi mitra dalam kegiatan ini adalah kelompok nelayan "Sukses Bahari". Kelompok ini merupakan salah satu kelompok nelayan yang dibentuk untuk menaungi anggota masyarakat nelayan di desa Marabombang.

\section{Permasalahan Mitra}

Jumlah nelayan di desa Marabombang cukup banyak. Hal ini disebabkan oleh lokasi geographis desa yang berbatasan langsung dengan laut. Namun demikian, masyarakat nelayan desa Marabombang juga menghadapi beberapa kendala dalam pengoperasian alat tangkap. Salah satu kendala yang dihadapi adalah penggunaan genset untuk menghasilkan energi listrik menggunakan bahan bakar bensin yang cukup boros. Oleh karena hal tersebut, nelayan terpaksa hanya menggunakan energi listrik untuk keperluan yang terbatas seperti menyalakan lampu berdaya rendah.

Selain itu, dengan mempertimbangkan biaya bahan bakar dan logistik, maka nelayan cenderung hanya memasang bagan mereka tidak terlalu jauh dari bibir pantai. Hal ini menyebabkan hasil tangkapan yang rendah dibandingkan bila dipasang agak menjauh dari bibir pantai (Ardidja, 2007). Selain itu, meningkatnya jumlah bagan yang dipasang menjadikan bibir pantai cukup padat dengan bagan sehingga ikan hasil tangkapan para nelayan juga menurun seiring meningkatnya jumlah bagan. 
Dari kondisi tersebut, dapat disimpulkan bahwa energi listrik menjadi salah satu sumber energi yang sangat vital bagi nelayan. Listrik ini menjadi salah satu faktor penentu produktivitas nelayan (Utomo, 2009). Untuk mendapatkan sumber listrik yang murah dan ramah lingkungan, maka perlu dipertimbangkan untuk menggunakan sistem hibrid yang menggabungkan sumber energi terbarukan yakni energi surya dengan genset sehingga lebih ramah lingkungan dan lebih mudah diaplikasikan.

\section{Metode Untuk Menangani Permasalahan}

Berdasarkan permasalahan yang dihadapi oleh masyarakat seperti yang dijelaskan di bab sebelumnya, tim berencana untuk memberikan pelatihan pengaplikasian sistem hibrid genset dan photovoltaic untuk menjadi sumber energi listrik pada bagan ikan di desa Marabombang, kecamatan Suppa, Kabupaten Pinrang.

Dari hasil survei awal yang dilakukan, diketahui bahwa terdapat 2 (dua) macam bagan ikan yang digunakan oleh masyarakat nelayan desa Marabombang yakni bagan ikan tancap dan bagan ikan terapung. Kedua bentuk bagan ini sangat cocok untuk memanfaatkan sistem hibrid genset dan photovoltaic karena beberapa bagian diatas bagan yang kosong sehingga dapat dimanfaatkan untuk menempatkan modul surya. Berikut contoh salah satu bagan ikan terapung.

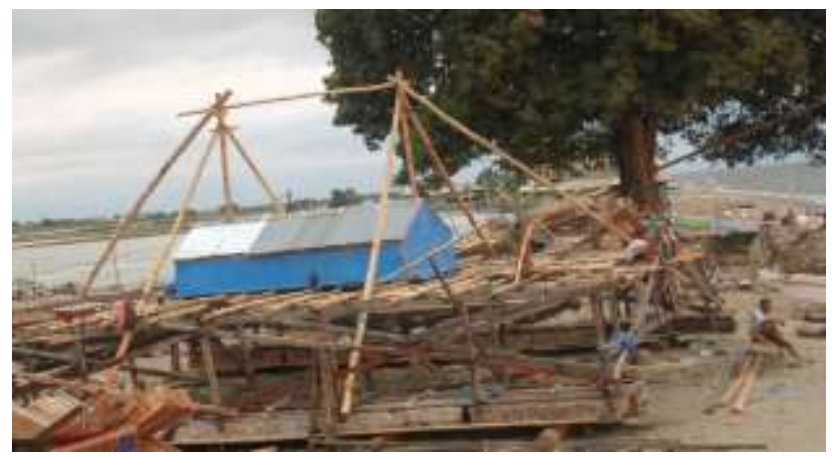

Gambar 2. Contoh Sebuah Bagan Ikan Terapung

Bagan yang digunakan juga mempunyai ukuran yang berbeda-beda namun kebanyakan mempunyai ukuran tinggi $2 \mathrm{~m}$ (tidak termasuk rumah bagan), lebar $9 \mathrm{~m}$, dan panjang $10 \mathrm{~m}$. Ukuran bagan ini yang akan digunakan dalam perencanaan dan sketsa penempatan sistem photovoltaic yang akan digunakan diatas bagan.

Dari gambar 2. bagan diatas, dapat terlihat bahwa beberapa bagian diatas bagan merupakan ruang kosong yang dapat digunakan untuk menempatkan modul surya. Dengan mempertimbangkan ruang untuk bekerja dan operasional bagan, penempatan modul surya disimulasikan. Dari sketsa simulasi penempatan modul surya, dapat diketahui bahwa ruang kosong diatas bagan mencukupi untuk menempatkan beberapa modul panel PV sehingga dapat menghasilkan daya yang cukup untuk pengoperasian bagan. Daya yang dihasilkan ini akan didukung oleh daya dari genset sebagai cadangan bila daya sistem PV tersebut tidak tercapai akibat misalnya kondisi cuaca berawan atau hujan. Dengan demikian, produktivitas dan nilai tangkapan nelayan dapat lebih maksimal. 


\section{Target Capaian}

Target utama dalam kegiatan ini adalah meningkatnya pemahaman dan pengetahuan masyarakat tentang pengaplikasian sistem hibrid genset dan photovoltaic sebagai sumber energi listrik pada bagan ikan. Selain itu, kegiatan ini juga akan mempraktekkan pemasangan dan pengoperasian sebuah sistem hibrid genset dan photovoltaic pada bagan ikan. Dengan pemahaman dan contoh aplikasi sebuah sistem photovoltaic, diharapkan adanya transfer teknologi sistem photovoltaic ke masyarakat nelayan sehingga masyarakat akan dapat menggunakan sistem tersebut untuk meningkatkan produktivitas yang pada akhirnya akan dapat meningkatkan kesejahteraan mereka.

Adapun luaran produk yang akan dihasilkan adalah sebuah contoh sistem hibrid genset photovoltaic yang diaplikasikan pada sebuah bagan ikan terapung. Berikut ini merupakan sketsa luaran yang akan dihasilkan:

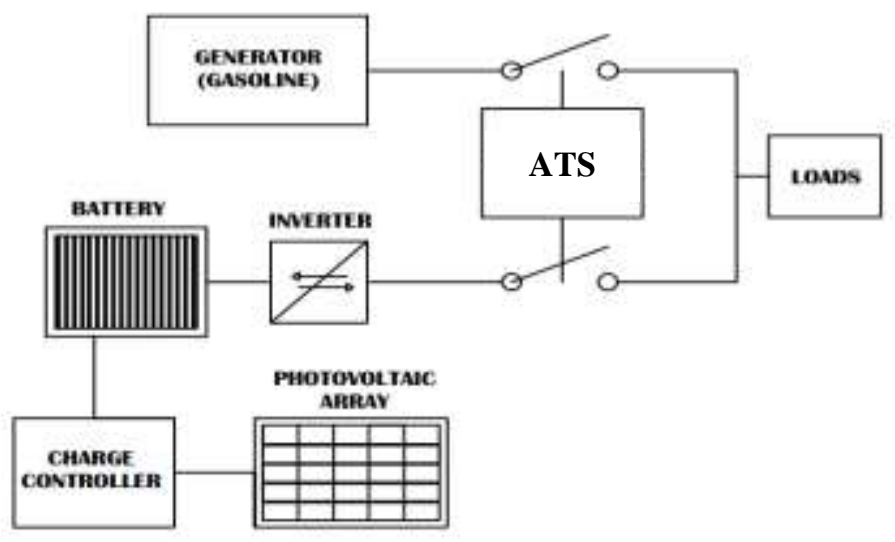

Gambar 3. Sketsa Luaran Sistem

\section{Implementasi Kegiatan}

\subsection{Persiapan Pelaksanaan}

Realisasi kegiatan tahapan awal yang dilakukan ialah berupa tahapan persiapan alat. Peralatan utama yang digunakan dalam memuat sistem hibrid adalah Automatic Transfer Switch (ATS). ATS merupakan sakelar yang bekerja otomatis, namun kerja otomatisnya berdasarkan memungkinan jika sumber listrik dari PLN terputus atau mengalami pemadaman maka saklar akan berpindah kesumber listrik yang lainnya misalnya adalah inverter (photovoltaic) atau generator. Adapun Automatic Transfer Swicth (ATS) yang akan digunakan seperti pada gambar dibawah ini:

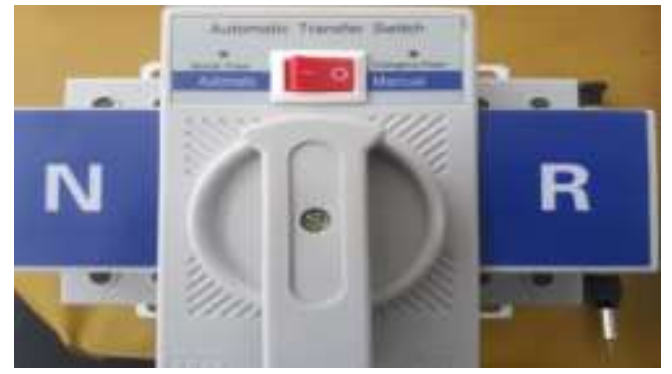

Gambar 4. Automatic Transfer Switch (ATS) 
Bagian dari Automatic Transfer Swicth terdiri dari sirkuit N (Normal power) yang menunjukkan sumber daya utama yang digunakan, sirkuit R (Reserve / Emergency power) yang menunjukkan sumber daya cadangan yang digunakan, indikator lampu serta switch untuk kondisi automatic dan kondisi manual. Sistem kerja dari Automatic Transfer Swicth dapat dipahami dengan mudah berdasarkan gambar dibawah ini:

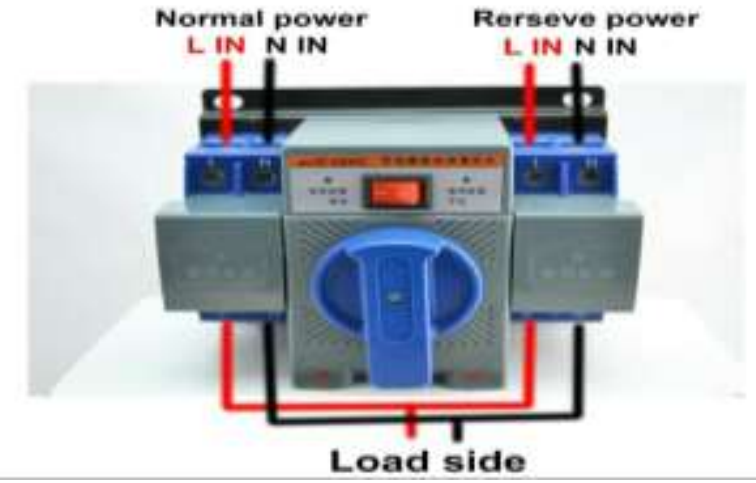

Gambar 5. Koneksi Automatic Transfer Switch (ATS)

Sumber daya utama dihubungkan pada sirkuit N (Normal power) sedangkan sumber daya cadangan dihubungkan pada sirkuit $\mathrm{R}$ (Reserve / Emergency power) pada bagian konektor atas Automatic Transfer Switch sebagai tegangan input sementara sumber beban/load dihubungkan pada bagian konektor bawah Automatic Transfer Switch sebagai tegangan ouput. Ketika sumber daya utama dihubungkan pada sirkuit N (Normal power) maka Automatic Transfer Swith dapat dioperasikan dengan switch pada kondisi automatic sehingga lampu indikator normal power akan menyala dan sumber daya akan langsung terhubung ke sumber beban/load maupun sebaliknya pada sumber daya cadangan. Ketika sumber daya utama dihubungkan pada sirkuit $\mathrm{N}$ (Normal power) dan sumber daya cadangan dihubungkan pada sirkuit $\mathrm{R}$ (Reserve powier) maka Automatic Transfer Switch dapat dioperasikan dengan switch pada kondisi automatic maupun manual.

Apabila mengarahkan switch pada kondisi automatic maka daya yang disalurkan ke sumber beban/load adalah daya dari sumber daya utama meskipun daya dari sumber cadangan juga aktif. Namun ketika sumber daya utama diputuskan maka otomatis sumber daya beban/load akan disalurkan dari sumber daya cadangan. Sementara jika mengarahkan switch pada kondisi manual maka sumber daya yang disalurkan tergantung dari posisi tunjukkan pada buttom secara manual. Jika menggeser buttom ke arah kiri maka sumber daya yang disalurkan berasal dari sumber daya utama sementara jika menggeser buttom ke arah kanan maka sumber daya yang disalurkan berasal dari sumber daya cadangan.

\subsection{Pelaksanaan}

Pelakasanaan kegiatan bimbingan aplikasi sistem hibrid genset dan photovoltaic pada masyarakat nelayan di suppa kabupaten pinrang telah dilakukan selama 2 hari sesuai jadwal yang telah direncanakan yakni tanggal 10-11 November 2018. Kegiatan hari pertama dilakukan dengan pemberian materi, demonstrasi langsung pemasangan alat dan sistem yang telah dirancang serta diskusi langsung dengan masyarakat nelayan dikawasan tersebut. Pembukaan kegiatan dilakukan oleh kepala desa Marabombang secara langsung dilokasi dan dihadiri oleh 
masyarakat nelayan desa Marabombang maupun nelayan sekitar. Suasana saat pembukaan kegiatan dapat dilihat pada gambar-gambar dibawah ini:

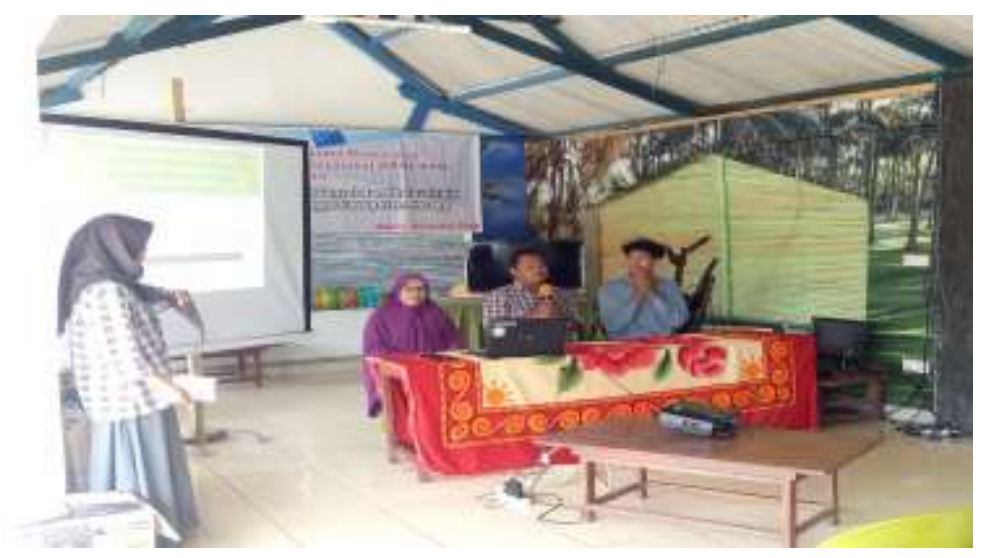

Gambar 6. Pembukaan Oleh Kepala Desa Marabombang

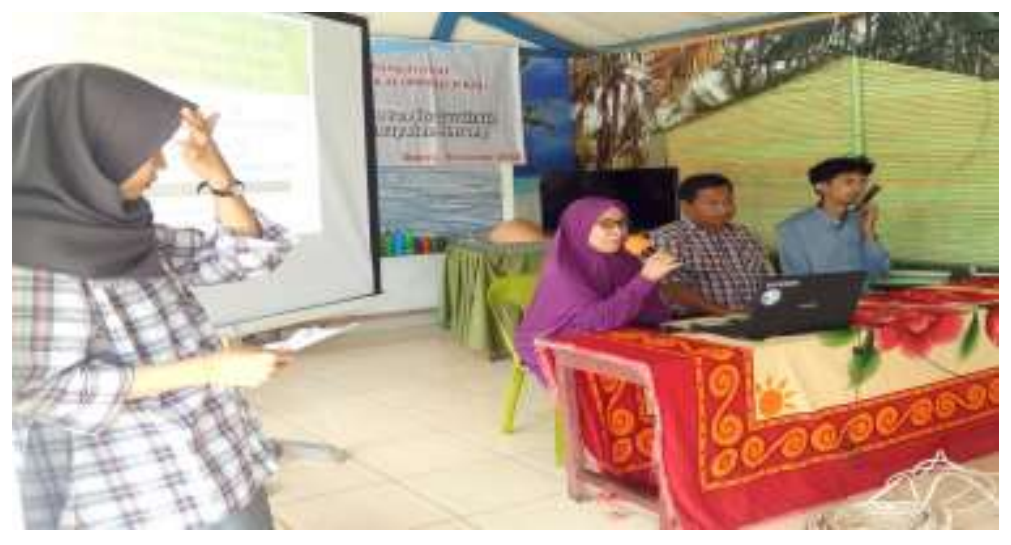

Gambar 7. Sambutan Kata Oleh Ketua Pengabdian

Pemberian materi mengenai aplikasi sistem pembangkit listrik hibrid panel surya (photovoltaic) dan generator dilakukan untuk memberikan gambaran secara umum kepada masyarakat nelayan mengenai komponen-komponen apa saja yang diperlukan untuk menerapkan sistem pembangkit listrik hibrid. Selain itu, melalui pemberian materi kepada masyarakat nelayan dapat memudahkan pemahaman tentang sistem pembangkit listrik hibrid sebelum dilakukan demonstrasi pemasangan alat dan sistem. 


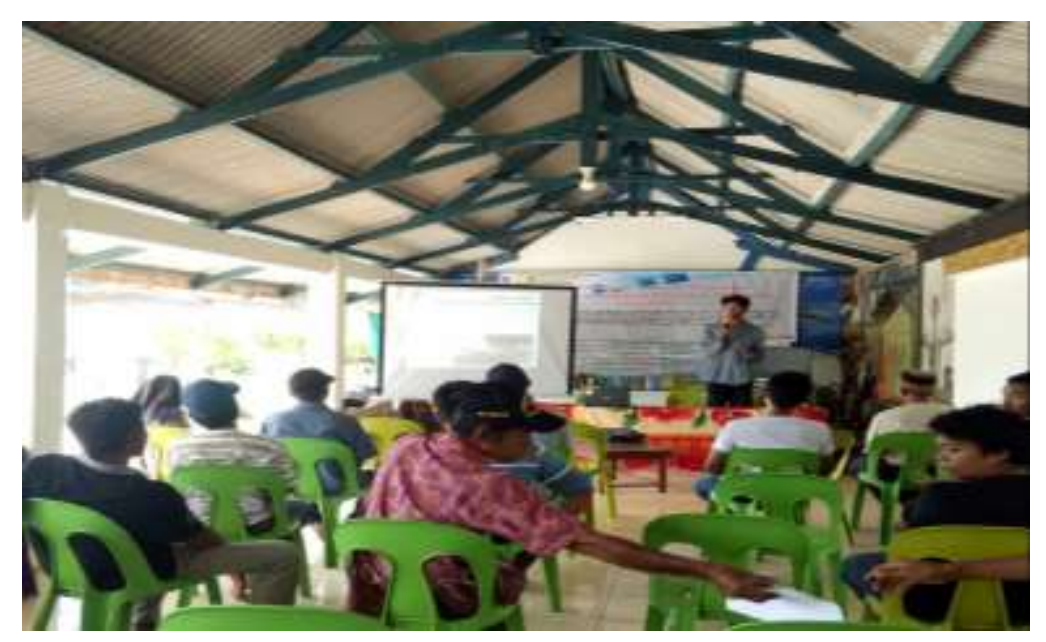

Gambar 8. Pemberian Materi

Demonstrasi pemasangan alat dan sistem yang telah dirancang dilakukan untuk menunjukan secara langsung komponen-komponen sistem pembangkit listrik hibrid kepada masyarakat nelayan. Antusias masyarakat semakin meningkat ketika demonstrasi pemasangan alat dan sistem telah dilakukan dan dilanjutkan dengan sesi diskusi langsung.

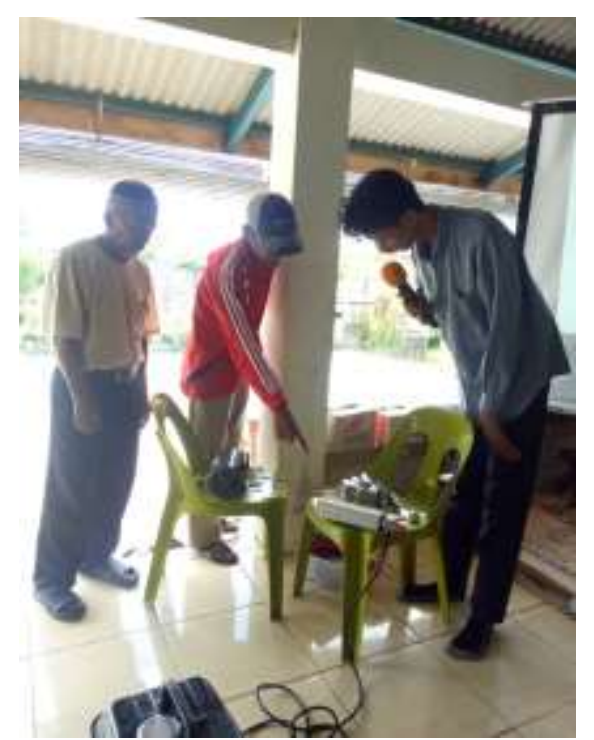

Gambar 9. Demonstrasi Dan Diskusi Langsung 


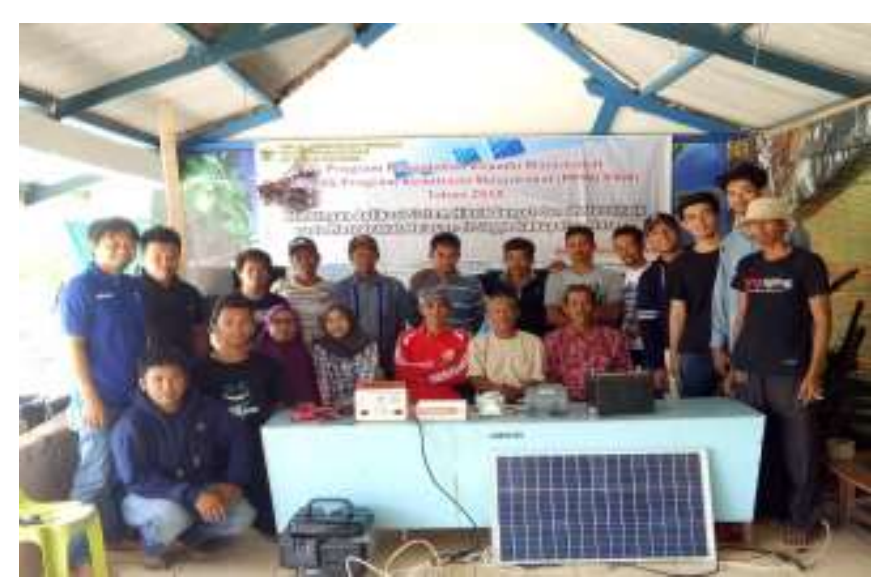

Gambar 10. Foto Bersama Masyarakat Nealayan Suppa

Kegiatan pada hari kedua adalah melakukan survei di sekitar kawasan pesisir desa Marabombang untuk melihat potensi penerapan sistem pembangkit listrik hibrid. Alhasil didapatkan bahwa sebagian masyarakat nelayan memiliki bagan apung di jarak 200-300 meter dari pinggir pantai. Bagan apung masyarakat nelayan suppa masih banyak yang mengandalkan generator sebagai sumber pembangkit listrik untuk penerangan lampu ketika menangkap ikan di malam hari.

\section{Kesimpulan}

Masyarakat nelayan Suppa Kabupaten Pinrang yang memiliki bagan ikan masih mengandalkan generator sebagai sumber pembangkit listrik untuk penerangan lampu ketika menangkap ikan. Atas dasar tersebut maka perlu dilakukan cara untuk mengurangi ketergantungan penggunaan generator yang bahan bakarnya mahal. Salah satu cara yang dapat dilakukan adalah menggunakan sistem pembangkit listrik hibrid, dimana sumber pembangkit listrik yang digunakan tidak bergantung 100\% pada generator. Panel surya (photovoltaic) merupakan sumber energi terbarukan yang paling mudah diterapkan di kawasan pesisir pantai. Berdasarkan hal tersebut, maka kegiatan bimbingan aplikasi sistem pembangkit listrik hibrid panel surya (photovoltaic) dan generator pada masyarakat nelayan Suppa Kabupaten Pinrang sangat perlu untuk dilakukan. Pelaksanaan bimbingan dilakukan dengan pemberian materi, demontrasi pemasangan alat dan sistem serta diskusi secara langsung untuk memudahkan masyarakat nelayan dalam memahami konsep serta komponen - komponen pada sistem pembangkit listrik hibrid panel surya (photovoltaic) dan generator.

\section{Ucapan Terima Kasih}

Ucapan Terima kasih diucapkan kepada Lembaga Penelitian dan Pengabdian Kepada Masyarakat (LPPM) Universitas Hasanuddin yang telah membiayai kegiatan. Selain itu, ucapan terima kasih juga disampaikan kepada Pemerintah Kabupaten Pinrang khususnya Kecamatan Suppa, warga masyarakat yang telah berpartisipasi dan seluruh tim pengabdian yang telah mensukseskan kegiatan ini.

\section{Daftar Pustaka}

Ardidja, S. (2007), Kapal Penangkap Ikan, Sekolah Tinggi Perikanan. Teknologi Penangkap Ikan. 
Haris, A. (2010). Profil Kelurahan Pallameang, diakses online, URL: http://putramoutong.blogspot.co.id/2010/09/profil-kelurahan-pallameang.html

Jahid, J. (2012). Studi Pengembangan Kecamatan Mattirosompe Sebagai Kawasan Minapolitan Kabupaten Pinrang, Jurnal Plano Madani, Vol. 4, No. 1, pp. 40-49.

Santosa, A.W.B., Mulyatno, I.P. (2014). Pemanfaatan Tenaga Angin dan Surya sebagai Alat Pembangkit Listrik pada Bagan Perahu, KAPAL, Vol. 11, No. 3.

Syah, R.N., Hardianto, T., Setiawan, A. (2014). Studi Kelayakan Atap Sel Surya sebagai Sumber Energi Listrik di Stasiun Kereta Api Jember, Artikel Ilmiah Hasil Penelitian Mahasiswa.

Susaniati, W., Nelwan, A.F.P., Kurnia, M., (2013). Produktivitas Daerah Penangkapan Ikan Bagan Tancap yang Berbeda Jarak dari Pantai Perairan Kabupaten Jeneponto, Jurnal Akuatika, Vol. 4, No. 1, pp. 68-79.

Utomo, T. (2009). Kajian Kelayakan Sistem Photovoltaic sebagai Pembangkit Daya Listrik Skala Rumah Tangga, Jurnal EECCIS, Vol. 3, No. 1. 